\title{
Economic Assessment of Solar Photovoltaics Use in Agricultural Greenhouses in Greece
}

\author{
John Vourdoubas
}

Correspondence: John Vourdoubas, Mediterranean Agronomic Institute of Chania, Agrokipio, 73100, Chania, Crete, Greece. Tel: 30-282-103-5020. Fax: 30-282-103-5001. E-mail: vourdoubas@maich.gr

Received: October 8, 2018

doi:10.5296/jas.v6i4.13896
Accepted: October 31, 2018

URL: https://doi.org/10.5296/jas.v6i4.13896

\begin{abstract}
Modern greenhouses can utilize renewable energy sources for covering their energy requirements and reducing their carbon footprint. Solar photovoltaics use for power generation is currently a reliable and cost-effective technology which is used in many applications. The purpose of the current work is to investigate the possibility of using solar photovoltaics in agricultural greenhouses in Greece and to assess their profitability compared with the profitability of their use in households. Semi-transparent and opaque photovoltaic cells can be used for electricity generation with the net-metering regulations covering all their annual electricity needs. Existing studies in various countries concerning their use in greenhouses have reported a payback period of the investments of 4-10 years. In Greece the cost of electricity in the agricultural sector is subsidized while economic incentives are offered regarding the use of this technology in greenhouses. Economic assessment of the investment of solar photovoltaics in greenhouses for a period of 25 years in Greece indicates payback periods of 7.2 and 14.4 years, depending on capital subsidies obtained, while positive net present values are achieved. Their use in households in Greece has a payback period of 10.4 years while the net present value is also positive. The current study indicates that the use of solar photovoltaics in modern greenhouses in Greece supported financially by the government according to the net-metering regulations is profitable, offering economic and environmental benefits to the farmers.
\end{abstract}

Keywords: agricultural greenhouses, Greece, net-metering, net present value, pay-back period, photovoltaics, profitability, solar energy

\section{Introduction}

The necessity to mitigate climate change requires the increased use of renewable energies replacing fossil fuels in all sectors of the economy including agriculture. Modern agricultural greenhouses are energy-intensive production systems consuming large amounts of heat and electricity. The use of sustainable energies in them could reduce the carbon footprint in 
agriculture. Current improvements in many sustainable energy technologies have decreased their cost and increased their reliability making their use more attractive for heat and power generation. However penetration of some renewable energy technologies in various economic sectors requires financial subsidies in order to improve their profitability. A period of attractive feed-in tariffs offered by the government in solar-PV installations in Greece was followed by a period with low feed-in tariffs while later the net-metering regulations were introduced. In fact the capital costs of solar photovoltaics (solar-PVs) have substantially decreased during the last years making their use attractive without any financial support. Their use for electricity generation either in stand-alone systems or in grid-connected buildings and enterprises with the net-metering regulations has increased in all countries. Use of solar-PV systems in greenhouses, apart from the environmental benefits, could result in an economic benefit for the farmer additional to the income of the cultivated crops. The recent years semi-transparent solar-PVs have been developed and their use on the rooftop of greenhouses has been studied. Advances also in organic photovoltaics, which currently have low efficiencies, have attracted attention and their future use in greenhouses has been investigated. Their installation on the rooftop should not result in excessive shadowing, decreasing crop productivity, while their use could decrease the indoor temperature and the cooling load during the summertime, also generating electricity covering part or all of the electricity requirements.

Squatrito et al, 2014 investigated the use of solar-PV systems in agricultural greenhouses in Sicily, Italy. The authors have performed a feasibility and profitability analysis of these systems estimating the payback period, the levelized cost of electricity (LCOE), the net present value and the internal rate of return. They found low payback periods in the range of 4-5 years, for nominal power of the solar-PVs at 10-20 KWp, high net present values and high rates of return. They also found that the LCOE was in the range of $0.116-0.140 € / \mathrm{KWh}$. Marrucci et al, 2013 investigated the use of photovoltaic covers in Mediterranean greenhouses. The authors have mentioned that flexible semi-transparent PV moduli should be used and placed on the rooftop of the greenhouses because the conventional rigid and opaque panels are not suitable. Cossu et al, 2010 reported on the use of grid-connected semi-transparent PV modulus on the rooftop of agricultural greenhouses in northern Sardinia, Italy. The range of the transparency in the modulus was between $50-75 \%$ and the authors have estimated the payback period of the investment at 10 to 13 years. Campiotti et al, 2012 reported on sustainable greenhouse horticulture in Europe. The authors estimated the payback period of grid-connected solar-PV installations with nominal power at $15 \mathrm{KWp}$ in greenhouses in Italy. The moduli were made from poly-crystalline silicon and the calculated payback period varied between 6 to 8 years depending on the geographical location. Tselepis, 2015 presented a study on the PV market development in Greece with net-metering regulations. The author has studied the profitability of solar-PV systems installed in households and in commercial enterprises concluding that both of them are financially attractive. The estimated payback period in households was below 12 years and in enterprises, without any subsidy, it was below 8 years. Net-metering regulations were introduced in Greece with the Ministerial Decree in December 2014 allowing the use of solar-PVs in grid-connected households and enterprises for electricity generation offsetting, on an annual 
basis, their consumption. Subsidies of the investment capital for solar-PV installations in agricultural greenhouses in Greece were allowed with a Ministerial Decree in December 2017 making the use of solar energy more attractive in them. Vourdoubas, 2016 studied the use of semi-transparent PVs placed on the rooftops in agricultural greenhouses in Crete, Greece. He found that in the case where they would cover less than $50 \%$ of their surface the energy generated could cover all their electricity needs, selling the surplus into the grid. Vourdoubas, 2016 also reported on the use of sustainable energies in agricultural greenhouses. The author mentioned that various renewable energies including solar energy, biomass and geothermal energy have been used for heat and electricity generation in greenhouses. Additionally sustainable energy technologies like co-generation of heat and power, heat pumps and waste heat reuse have been used in them. Aroca-Delgado et al, 2018 have presented an extensive literature review concerning the use of solar-PVs as shading systems in greenhouses. The authors concluded that further research is required to determine the optimum percentage of panels that does not reduce agricultural production. Castellano et al, 2014 investigated the shading effect of solar-PVs placed on the rooftops of agricultural greenhouses. The authors performed computer simulations and developed a model to estimate the shading effect concluding that further research is needed in order to calibrate the model. Sgroi et al, 2014 studied the Italian energy policy with reference to the solar-PV installations in greenhouses. The authors reported that the use of solar-PVs with capacity greater than $50 \mathrm{KW}$ covering all the electricity needs of greenhouses in Italy with net-metering regulations is profitable. It would also be profitable in the future if the prices of solar-PVs decreases and the cost of electricity increases. Kocar et al, 2018 examined the integration of solar technology in modern greenhouses. The authors reported that solar-PV systems can generate the electricity required in the greenhouses which could be $20-30 \%$ of their total energy demand. They also mentioned that the payback period of the solar-PV systems varies between 4 and 8 years depending on the climatic conditions and the type of crop. Carreno-Ortega et al, 2017 investigated the use of solar-PV systems in greenhouses located in Almeria, Spain which has the highest concentration of greenhouses in Europe. Implementing sensitivity analysis, the authors concluded that their use is profitable and it would increase their economic benefit by $0.88-52.78 \%$. Hassanien et al, 2016 reviewed the state of the art solar energy applications in agricultural greenhouses. They reported that solar energy can provide cheap and clean energy for agricultural greenhouses all over the world. They have also proposed that the governments should offer attractive incentives to promote these technologies. Li et al, 2017 reported on the integration of solar-PV systems in agricultural greenhouses in China. Implementing five case studies in photovoltaic greenhouses, they estimated an attractive payback period of 4-8 years which, they mentioned, depends on the cultivated crops. Bambara et al, 2018 investigated the use of a semi-transparent PV on the roof of a greenhouse in Ottawa, Ontario, Canada. The authors mentioned that due to shading artificial lighting was required. Although the solar-PV was generating electricity, the authors concluded that the use of the solar-PV in the greenhouse was not an economically attractive investment. Trypanagnostopoulos et al, 2017 investigated the use of solar-PVs on the rooftop of greenhouses growing lettuce in Greece. The photovoltaics created 20\% shading but the authors reported that the crop's productivity was not decreased. They concluded that 
solar-PVs installed in greenhouses could cover part or all of their electricity requirements without affecting plant growth. Xue, 2017 reported on the economic assessment of photovoltaic greenhouses in China. His results have indicated that the profitability of the solar energy systems depends on the size of the greenhouses, the photovoltaics costs, the cost of electricity and the income from the crops. The estimated payback time for the solar-PV's investments varied greatly from less than 4 years to over 25 years. Tudisca et al, 2013 assessed the Italian energy policy through the study of a solar-PV investment on a grid-connected greenhouse in Sicily. The authors mentioned that the minimum feed-in tariff for the farmer to obtain a profit, equal to $0.148 € / \mathrm{KWh}$, is far less than that granted by the Italian government at $0.422 € / \mathrm{KWh}$. They concluded that, due to high feed-in tariffs, the energy income for the farmer would be higher than the income obtained through the crop cultivation. Emmott et al, 2015 investigated the use of organic transparent photovoltaics in greenhouses. The authors mentioned that, although they have some advantages, technically organic PVs do not perform better than conventional opaque crystalline cells while future cost reductions might improve their cost efficiency. Cuce et al, 2016 presented a review regarding the use of sustainable energy technologies in agricultural greenhouses including solar-PVs. The authors mentioned that solar-PV systems are the simplest technology to produce electricity in greenhouses. However, conventional PV moduli have low efficiencies at $14-20 \%$. Additionally in countries with high solar irradiance during the summer their temperature could rise $50^{\circ} \mathrm{C}$ above ambience, resulting in a significant decrease of their efficiency. Moazenzadeh et al, 2018 have reported on evaporation prediction in Northern Iran. The authors have identified two parameters with high influence in water evaporation which were used as input in appropriate models to simulate evaporation values on a daily scale. The authors found that the two parameters with the highest impact in water evaporation were net solar radiation and saturation vapor pressure deficit.

The aims of the current work are:

1. The investigation of the feasibility and profitability of using solar-PVs in agricultural greenhouses with net-metering regulations in Greece, and

2. The comparison of the profitability of solar-PVs use in agricultural greenhouses and in households in Greece.

\section{Energy Requirements in Modern Greenhouses}

Modern greenhouses require energy for covering their energy needs for heating, cooling, lighting and the operation of various equipment and machinery. In a modern greenhouse in Greece the share of space heating to the total energy requirements could exceed $90 \%$ while the share of electricity would be below $10 \%$. Currently the most appropriate technology for offsetting grid electricity consumption in greenhouses is the use of opaque crystalline photovoltaic cells. Generated electricity is directly used or it is stored into the grid, if it is not needed, and it is used later. During the day time in the summertime the productivity of the solar-PV system is high while electricity is needed for space cooling in the greenhouse. Therefore better synchronization during the summer between electricity generation and consumption is obtained. The combination of using renewable energy sources, like solid biomass or geothermal energy, for space heating and solar photovoltaic energy for electricity 
generation could result in zero-carbon emissions due to operational energy use in modern greenhouses. The technologies related with heat production from solid biomass and geothermal fluids, if available, and with electricity generation from solar energy, are mature, reliable and cost-effective. Similarly the technologies of industrial waste heat reuse and ground source heat pumps are mature and reliable. Therefore the use of solar-PVs, as well as other benign energy sources, in modern greenhouses would result in the mitigation of climate change in the primary sector. Sustainable energies which can be used for covering the energy requirements in greenhouses are presented in Table 1.

Table 1. Renewable energy sources and sustainable energies with zero carbon impact which can be used for covering the energy requirements in greenhouses in Greece

\begin{tabular}{l|l|l}
\hline Renewable energy & Technology & Generated energy \\
\hline Solar & Photovoltaic & Electricity \\
\hline Solid biomass & Burning & Heat \\
\hline Low temperature geothermal fluids & Heat exchange & Heat \\
\hline Low enthalpy geothermal energy & Ground source heat pumps & Heat and cooling \\
\hline Industrial waste heat & Heat exchange & Heat \\
\hline
\end{tabular}

Source: Vourdoubas, 2016

\section{Cost of Electricity in Greece in Agricultural Enterprises and in Households}

Electricity cost in Greece is different in agricultural enterprises and in households. Its cost in households varies from $0.09460 € / \mathrm{KWh}$ for low energy consumption [less than $2000 \mathrm{KWh}$ per four months] up to $0.10252 € / \mathrm{KWh}$ for high energy consumption [higher than $2000 \mathrm{KWh}$ per four months]. Additional costs are included in the electricity bills like municipal taxes, VAT $(13 \%)$, electricity transmission costs etc. In fact the total final electricity cost in households could be as high as $0.25 € / \mathrm{KWh}$. In agricultural enterprises electricity costs are significantly lower than in households at $0.06412 € / \mathrm{KWh}$. This low price is justified due to governmental subsidies of the electricity cost in agricultural enterprises in order to increase the competitiveness of the primary sector. Additional costs are limited and significantly less than in households while agricultural enterprises are recovering VAT. In fact electricity cost in agricultural enterprises is approximately 30-35\% lower than in households. Therefore since the share of fossil fuels in the electricity mix is high, the government indirectly supports the use of fossil fuels in agriculture. This is a counter-incentive of using renewable energies in agriculture in Greece. The current cost of electricity in Greece for households and agricultural enterprises is presented in Table 2. 
Table 2. Cost of electricity in Greece ${ }^{1,2,3}$

\begin{tabular}{l|l}
\hline Sector & Cost of electricity \\
\hline In agricultural activities & $0.06412 € / \mathrm{KWh}$ \\
\hline In households & $0.09460 € / \mathrm{KWh}$ (for consumption up to 2 \\
& $000 \mathrm{KWh}$ per 4 months) \\
\hline In households & $\begin{array}{l}0.10252 \quad € / \mathrm{KWh} \mathrm{(for} \mathrm{consumption} \\
\text { exceeding } 2000 \mathrm{KWh} \text { per } 4 \text { months) }\end{array}$ \\
\hline
\end{tabular}

1. without VAT

2. Electricity costs in households

3. Electricity cost in agricultural enterprises

\section{Net-Metering Regulations and Solar-PVs Uses in Greece}

The net-metering regulations were firstly introduced in Greece in December 2014 with a Ministerial decision [Ministerial Decree 24461/30-12-2014]. Previously attractive feed-in tariffs up to $0.55 € / \mathrm{KWh}$ were offered for solar-PV systems generating electricity injected into the grid. Currently though the installation of solar-PVs in greenhouses is allowed only with the net-metering regulations. The program started a few months later in 2015 for the low voltage solar-PV systems. According to the net-metering regulations excess electricity produced by a solar-PV could be injected and stored into the grid if it is not needed. This electricity can be used later when required and if the on-site electricity generation is not sufficient to cover the needs. Therefore the electric grid is acting as an electric battery, storing the solar electricity when it is not needed. The program supports private and public entities who can install solar-PVs with nominal capacity less than $20 \mathrm{KWp}$, in non-interconnected islands in Greece like Crete, generating electricity for 25 years. The photovoltaic system can be mounted on the building/greenhouse or in places located away from the building/greenhouse according to the virtual net-metering regulations. The balance of the grid electricity consumed with green electricity generated by the solar-PVs is calculated on an annual basis. Three years after the initiation of the net-metering regulations its acceptance from households and enterprises is rather limited below the initial expectations.

\section{Financial Subsidies of Solar-PV Systems Installed in Agricultural Enterprises With Net-Metering Regulations in Greece}

In order to support the use of solar-PV systems with net-metering regulations in the agricultural sector in Greece the government, since 2017, subsidizes their initial investment cost [Ministerial Decree 13158/11-12-2017]. The percentage of the initial investment cost which is subsidized varies between $40-85 \%$ depending on the geographical area in the country and the characteristics of the investor. The initial investment capital must be between $10000 €$ and $150000 €$. It should be noted that electricity synchronization in agricultural enterprises is less important than in households since it has low influence in the final benefits obtained. However modern greenhouses need space cooling during the summer when the solar irradiance in Greece is high. In this period the generated electricity can be consumed immediately in the greenhouses without being stored into the grid. 


\section{Economic Assessment of Solar-PVs Installed in Agricultural Greenhouses in Crete,} Greece

Solar-PVs can be installed either on the rooftop in the greenhouses or on the ground in a nearby area. In the case that they are installed on the rooftop they might be transparent, which has a greater cost at the moment, or opaque crystalline cells. In the latter case, the resulting shadowing should not reduce the crop's productivity. Assessment of the economic viability of solar-PV systems installed in agricultural greenhouses in Greece with or without financial subsidies has been made with the following assumptions:

a) The solar-PV system with opaque crystalline panels and nominal capacity at $15 \mathrm{KWp}$ will cover the annual electricity consumption in the greenhouse for a period of 25 years,

b) The solar-PV is installed on the ground in a nearby area, and

c) The capital cost is covered by the owner without any bank loan.

Various parameters of the solar-PV system installed in a greenhouse are presented in Table 3.

Table 3. Economic assessment of a solar-PV system installed in an agricultural greenhouse in Crete, Greece ${ }^{1}$

\begin{tabular}{|c|c|c|}
\hline & Without subsidies & $\begin{array}{l}\text { With initial } 50 \% \text { subsidy of the } \\
\text { investment }\end{array}$ \\
\hline Nominal power & $15 \mathrm{KWp}$ & $15 \mathrm{KWp}$ \\
\hline Energy consumption & $18500 \mathrm{KWh} /$ year & $18500 \mathrm{KWh} /$ year \\
\hline Duration & 25 years & 25 years \\
\hline $\begin{array}{l}\text { Initial annual productivity of the } \\
\text { solar-PV }\end{array}$ & $1500 \mathrm{KWh} / \mathrm{KWp}$ & $1500 \mathrm{KWh} / \mathrm{KWp}$ \\
\hline $\begin{array}{l}\text { Annual decrease of the solar-PV } \\
\text { productivity }\end{array}$ & $0.5 \%$ & $0.5 \%$ \\
\hline Annual discount rate & $2 \%$ & $2 \%$ \\
\hline $\begin{array}{l}\text { Initial energy production of the } \\
\text { solar-PV }\end{array}$ & $22500 \mathrm{KWh} /$ year & $22500 \mathrm{KWh} /$ year \\
\hline $\begin{array}{l}\text { Final energy production of the } \\
\text { solar-PV }\end{array}$ & $>18500 \mathrm{KWh} /$ year & $>18500 \mathrm{KWh} /$ year \\
\hline Initial investment $^{I}$ & 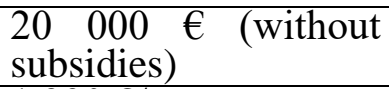 & $\begin{array}{l}10000 €(50 \% \text { subsidies in the } \\
\text { initial capital })\end{array}$ \\
\hline Annual savings & $1390 € /$ year & $1390 € /$ year \\
\hline Payback period & 14.4 years & 7.2 years \\
\hline Net present value & $7348 €$ & $15700 €$ \\
\hline $\begin{array}{llll}\text { Ratio of } & \text { NPV } & \text { to } & \text { initial } \\
\text { investment }\end{array}$ & $36.74 \%$ & $157 \%$ \\
\hline
\end{tabular}

1 VAT $23 \%$ is deducted in agricultural greenhouses

2 Average annual electricity generation per KWp of solar-PVs in Greece

The net present value calculated without subsidies is $7348 €$ corresponding to $36.74 \%$ of the initial capital investment. In the case that the initial capital is subsidized by $50 \%$ the net present value calculated is $15700 €$ corresponding to $157 \%$ of the initial capital investment. Therefore the initial capital subsidy improves significantly the profitability of the solar-PV system installed in the greenhouse. 


\section{Ml Macrothink}

Journal of Agricultural Studies

ISSN 2166-0379

2018, Vol. 6, No. 4

\section{Economic Assessment of Solar-PVs Installed in Households in Crete, Greece}

During the last years after the introduction of net-metering regulations, many households in Greece have installed solar-PV systems offsetting their electricity consumption. For the economic assessment of such systems the following assumptions have been made:

a) The solar-PV system with opaque crystalline panels and a nominal capacity of $2.5 \mathrm{KWp}$ will cover the annual electricity consumption in the households for a period of 25 years, and

b) The capital cost is covered by the owner without any bank loans.

Various parameters of the solar-PV system are presented in Table 4. The payback period of the investment has been estimated at 10.4 years and its net present value at $4536 €$. If the synchronization rate, which has been assumed at $24 \%$, is increased the economics could probably be improved.

Table 4. Economic assessment of a solar-PV system installed in a residential building in Crete, Greece

\begin{tabular}{l|l}
\hline Nominal power & $2.5 \mathrm{KWp}$ \\
\hline Energy consumption $^{1}$ & $3000 \mathrm{KWh} /$ year \\
\hline Initial energy production & $3750 \mathrm{KWh} /$ year \\
\hline Annual decrease of solar-PV productivity & $0.5 \%$ \\
\hline Energy production after 25 years & $>3000 \mathrm{KWh} /$ year \\
\hline Operating period & 25 years \\
\hline Initial investment & $5200 €$ \\
\hline Annual discount rate & $2 \%$ \\
\hline Pay-back period & 10.4 years \\
\hline Net present value & $4536 €$ \\
\hline Annual electricity generation & $1500 \mathrm{KWh}$ per KWp \\
\hline Synchronization rate & $24 \%$ \\
\hline Ratio of NPV to initial investment & $87.23 \%$ \\
\hline
\end{tabular}

1 Average annual electricity consumption in households in Greece

The net present value is calculated at $4536 €$ corresponding to $87.23 \%$ of the initial investment. 


\section{Discussion}

Solar-PV technology is currently a simple, mature, reliable and cost-effective technology for electricity generation in various sectors including greenhouses. Various studies have been implemented in various countries assessing its economic profitability. The majority of them have concluded that their use is profitable and the estimated payback time varies between 4 to 8 years. Conventional solar-PV systems with opaque silicon crystalline cells are the conventional and cheapest technology used. Semi-transparent PV cells are still more expensive than opaque. The organic photovoltaics are not mature yet while they could be used in the future. The use of solar-PVs in agricultural greenhouses was supported in many countries with attractive feed-in tariffs some years ago. Currently farmers can install those systems in grid-connected greenhouses with the net-metering initiative producing the electricity that they consume annually, making them 'pro-sumers'. The cost of electricity, which is mainly produced by fossil fuels, in the agricultural sector in Greece, is subsidized by the government. This is a counter-incentive in using renewable energies for power generation in greenhouses. Due to low grid electricity cost used in greenhouses the payback period of the solar-PV investment has been estimated at 14.4 years. However currently the Greek government subsidizes the installation of solar-PVs in greenhouses, offering attractive incentives which could exceed $50 \%$ of the initially invested capital. Due to these capital incentives the payback period of the solar-PV investment is decreased to 7.2 years. The fact that many greenhouses in Greece are simple village-type constructions with a life span of less than 15 years does not facilitate the use of solar-PVs in them, which is profitable in the long run. Therefore this fact limits their use only in modern highly automated greenhouses. The cost of electricity in households in Greece is higher than in greenhouses and there is no financial support concerning the installation cost of solar-PVs in them. Comparing the profitability of solar-PV use in greenhouses and in households, the estimated payback period for the installation of a solar-PV in a household is 10.4 years. The payback period for solar-PV investments in greenhouses in various countries according to various studies is presented in Table 5. Our calculations confirm the results presented by Tselepis, 2015, regarding the profitability of solar-PV investments with net-metering regulations in Greece, indicating that the payback period for solar-PV investments in households was below 12 years and in enterprises, without subsidies in the electricity's cost, was below 8 years. 
Table 5. Payback period for solar-PV systems installed in agricultural greenhouses in the existing literature

\begin{tabular}{l|l|l|l|l}
\hline Source & Country & $\begin{array}{l}\text { Size of the PV } \\
\text { system } \\
(\mathrm{KWp})\end{array}$ & $\begin{array}{l}\text { Type of PV } \\
\text { system }\end{array}$ & $\begin{array}{l}\text { Payback } \\
\text { period } \\
\text { (years) }\end{array}$ \\
\hline Squatrito et al, 2014 & Sicily, Italy & $10-20$ & Crystalline & $4-5$ \\
\hline Campiotti et al, 2012 & Italy & 15 & Crystalline & $6-8$ \\
\hline Cossu et al, 2010 & $\begin{array}{l}\text { Sardinia, } \\
\text { Italy }\end{array}$ & & Semi-transparent & $10-13$ \\
\hline Kocar et al, 2018 al, & Surkey & & & $4-8$ \\
\hline $\begin{array}{l}\text { Carreno-Ortega et } \\
\text { Li et al, 2017 }\end{array}$ & China & & Crystalline & Profitable \\
\hline Xue, 2017 & China & & & $4-8$ \\
\hline
\end{tabular}

The economic assessment of solar-PV use in greenhouses and in households in Greece is presented in Table 6.

Table 6. Economic assessment of solar-PV use in households and agricultural greenhouses in Greece with net-metering regulations ${ }^{1,2,3}$.

\begin{tabular}{l|l|l|l}
\hline & $\begin{array}{l}\text { Agricultural greenhouse } \\
\text { without subsidies in the } \\
\text { initial energy investment }\end{array}$ & $\begin{array}{l}\text { Agricultural greenhouse } \\
\text { with 50\% subsidy of the } \\
\text { initial energy investment }\end{array}$ & Household \\
\hline $\begin{array}{l}\text { Payback period } \\
\text { (years) }\end{array}$ & 14.4 & 7.2 & 10.4 \\
\hline $\begin{array}{l}\text { Net present value } \\
(€)\end{array}$ & 7348 & 15700 & 4536 \\
\hline $\begin{array}{l}\text { Ratio of NPV to } \\
\text { initial investment } \\
(\%)\end{array}$ & 36.74 & 157 & 87.23 \\
\hline
\end{tabular}

1. Nominal power less than $20 \mathrm{KWp}$

2. The investment capital is covered by the owner

3. For a period of 25 years

\section{Conclusions}

Use of sustainable energies in agricultural greenhouses for covering their energy needs results in mitigation of climate change. In recent years the decrease in the cost of solar-PVs combined with new regulations regarding their use in various applications have increased their attractiveness in electricity generation. Solar-PVs can be used in grid-connected agricultural greenhouses for electricity generation with net-metering regulations, reducing the annual electricity expenses and offering an additional economic benefit to the farmer together with environmental benefits. Various studies implemented so far in various countries concerning the use of semi-transparent and opaque moduli have demonstrated the economic benefits resulting from the use of this technology. The majority of the results of these studies indicated that the payback period of solar-PV investments in greenhouses varies from 4 to 10 years. In Greece the government subsidizes the cost of electricity in the agricultural sector in order to increase its competitiveness. At the same time it offers economic subsidies to the capital invested in solar-PVs in greenhouses. Published results concerning the use of 
solar-PVs in agricultural greenhouses in various countries have reported payback periods between 4-10 years while in few cases the payback periods were higher up to 25 years. Economic assessment of solar-PV investments in greenhouses in Greece has indicated that the payback period varies from 7.2 years, when the invested capital is subsidized, to 14.4 years without capital subsidies. Additionally in both cases the estimated NPV is positive. In a typical Greek household a solar-PV system with nominal power at $2.5 \mathrm{KWp}$ and cost at 5,200 €could generate annually the amount of grid electricity consumed. Comparing the profitability of solar-PV investments with net-metering regulations in households in Greece, the estimated payback period was 10.4 years, while the NPV was also positive. Realization of an agricultural greenhouse which covers all its annual electricity needs with solar-PV electricity for demonstration purposes is needed, preferably in Crete where almost half of the Greek greenhouses are located. Additionally the current Greek governmental policy offering low electricity costs in agricultural greenhouses should change, since it acts as a counter incentive for the promotion of renewable energies in agriculture. Mitigation of climate change requires the removal of all hidden subsidies to fossil fuels and promotion of sustainable energy sources with various policies.

\section{References}

Aroca-Delgado, R., Perez-Alonso, J., Callejon-Ferre, A. J., \& Velazquez-Marti, B. (2018). Compatibility between crops and solar panels: An overview from shading systems, Sustainability, 10, 743. https://doi.org/10.3390/su10030743

Bambara, J., \&Athienitis, A. K. (2018). Energy and economic analysis for the design of greenhouses with semi-transparent photovoltaic cladding, Renewable Energy, 1-14, https://doi.org/10.1016/j.renene.2018.08.020

Campiotti, C., Viola, C., Alonzo, G., Bibbiani, C., Giagnacovo, G., Scoccianti, M., \& Tumminelli, G. (2012). Sustainable greenhouse horticulture in Europe, Journal of Sustainable Energy, 3(3).

Carreno-Ortega, A., Galdeano-Gomez, E., Perez-Mesa, J. C., \& Galera-Quiles, M. D. C. (2017). Policy and environmental implications of Photovoltaic systems in Farming in Southeast Spain: Can Greenhouses reduce the Greenhouse effect?, Energies, 10, 761. https://doi.org/10.3390/en10060761

Castellano, S. (2014). Photovoltaic greenhouses: Evaluation of shading effect and its influence on agricultural performance, Journal of Agricultural Engineering, 433, 168-175. https://doi.org/10.4081/jae.2014.433

Cossu, M., Murgia, L., Caria, M., \& Pazzona, A. (2010). Economic feasibility study of semi-transparent photovoltaic technology integrated on greenhouse covering structures, International Conference Ragusa SHWA2010 - September 16-18, 2010 Ragusa Ibla CampusItaly "Work Safety and Risk Prevention in Agro-food and Forest Systems", 648-655.

Cuce, E., Harjunowibowo, D., \& Cuce, P. M. (2016). Renewable and sustainable energy saving strategies for greenhouse systems: A comprehensive review, Renewable and Sustainable Energy Reviews, 64, 34-59. https://doi.org/10.1016/j.rser.2016.05.077 
Electricity cost in agricultural enterprises in Greece, at https://www.dei.gr/Documents2/TIMOLOGIA/01-01-2018-FINAL/XT-1-1-18-FINAL/Agrot iko\%20Timologio\%20A4-1-1-18-\%CE\%95\%CE\%A4\%CE\%9C\%CE\%95\%CE\%91\%CE\%A 1.pdf

Electricity cost in households in Greece, at https://www.dei.gr/Documents2/TIMOLOGIA/01-01-2018-FINAL/XT-1-1-18-FINAL/Oikia ko\%20Timologio\%20G1\%20A4-1-1-18-\%CE\%95\%CE\%A4\%CE\%9C\%CE\%95\%CE\%91\% CE\%A1.pdf

Emmott, C. J. M., Rohn, J. A., Campoy-Quiles, M., Kirchartz, T., Urbina, A., Ekins-Daukes, N. J., \& Nelson, J. (2015). Organic photovoltaics greenhouse: a unique application for semi-transparent PV? Energy and Environmental Science, 8, 1317-1328. https://doi.org/10.1039/C4EE03132F

Hassanien, R., Hassanien, E., Li, M., \& Lin, W. D. (2016). Advanced applications of solar energy in agricultural greenhouses, Renewable and Sustainable Energy Reviews, 54, 989-1001. https://doi.org/10.1016/j.rser.2015.10.095

Kocar, G., Eryasar, A., Godekmerdan, E., Ozgul, S., \&Duzenli, M. (2018). A prospect on integration of solar technology to modern greenhouses, Journal of Science and Engineering, 20(58), 245-258. https://doi.org/10.21205/deufmd. 2018205820

Li, C., Wang, H., Miao, H., \& Ye, B. (2017). The economic and social performance of integrated photovoltaic and agricultural greenhouse systems: Case study in China, Applied Energy, 190, 204-212. https://doi.org/10.1016/j.apenergy.2016.12.121

Marruci, A., Gusman, A., Pagnello, B., \& Cappuccini, A. (2013). Limits and prospects of Photovoltaic cover in Mediterranean greenhouses, Journal of Agricultural Engineering, 44(1). https://doi.org/10.4081/jae.2013.e1

Ministerial Decree 13158/11/12/2017, Greek Ministry of Agricultural Development, Promotion of investments of RES in Agriculture, ФEK 4302/11-12-2017.

Ministerial, D. (2014). Greek Ministry of Environment, Energy and Climatic Change (YPEKA), 30/12/2014, АПЕНК/А/Ф1/ок.24461, (ФЕКВ’3583/31.12.2014).

Moazenzadeh, R., Mohammadi, B., Shamshirband, S., \& Chau, K. W. (2018). Coupling a firefly algorithm with support vector regression to predict evaporation in northern Iran, Engineering Applications of Computational Fluid Mechanics, 12(1), 584-597. https://doi.org/10.1080/19942060.2018.1482476

Sgroi, F., Tudisca, S., Di Trapani, A. M., Testa, R., \& Squatrito, R. (2014). Efficacy and Efficiency of Italian Energy Policy: The Case of PV Systems in Greenhouse Farms , Energies, 7(6), 3985-4001. https://doi.org/10.3390/en7063985

Squatrito, R., Sgroi, F., Tudisca, S., Di Trapani, A. M., \& Testa, R. (2014). Post feed-in Scheme Photovoltaic system feasibility evaluation in Italy: Sicilian Case Studies, Energies, 7, 7147-7165. https://doi.org/10.3390/en7117147 


\section{Macrothink}

Journal of Agricultural Studies

ISSN 2166-0379

2018, Vol. 6, No. 4

Trypanagnostopoulos, G., Kavga, A., Souliotis, M., \& Trypanagnostopoulos, Y. (2017). Greenhouse performance results for roof installed photovoltaics, Renewable Energy, 111, 724-731. https://doi.org/10.1016/j.renene.2017.04.066

Tselepis, S. (2015). The PV Market Developments in Greece, Net-Metering Study Cases. Retrieved at 25/6/2018 from

http://www.cres.gr/kape/publications/photovol/new/S\%20\%20Tselepis\%20\%20The\%20PV\% 20Market $\% 20$ Developments $\% 20$ in $\% 20$ Greece $\% 20 \% 20$ Net-Metering\%20Study $\% 20 \mathrm{Cases} \% 2$ 031st\%20EUPVSEC\%202015\%20Hamburg\%20\%207DV.4.26.pdf

Tudisca, S., Di Trapani, A. M., Sgroi, F., Testa, R., \& Squatrito, R. (2013). Assessment of Italian energy policy through the study of a photovoltaic investment on greenhouse. African Journal of Agricultural Research, 8(24), 3089-3096.

http://dx.doi.org/10.5897/AJAR2013.7406

Vourdoubas, J. (2016). Overview of the use of sustainable energies in agricultural greenhouses, Journal of Agricultural Science, 8(3), 36-43.

https://doi.org/10.5539/jas.v8n3p36

Vourdoubas, J. (2016). Possibilities of using semi-transparent photovoltaic modules on rooftop of greenhouses for covering their energy needs, Journal of Agricultural Studies, 4(1), 90-100. https://doi.org/10.5296/jas.v4i1.8694

Xue, J. (2017). Economic assessment of photovoltaic greenhouses in China, Journal of Renewable and Sustainable Energy, 9, 033502. https://doi.org/10.1063/1.4982748

\section{Copyright Disclaimer}

Copyright for this article is retained by the author(s), with first publication rights granted to the journal.

This is an open-access article distributed under the terms and conditions of the Creative Commons Attribution license (http://creativecommons.org/licenses/by/4.0/). 